\title{
Metastatic Uveal Melanoma-A Review of Current Therapies and Future Directions
}

\author{
Emily N Kinsey ${ }^{1}$ and April KS Salama² \\ 1. Department of Internal Medicine, Duke University Medical Center, Durham, NC, US; 2. Division of Medical Oncology, Duke University Medical \\ Center, Durham, NC, US
}

DOl: https://doi.org/10.17925/OHR.2017.13.02.100

\section{Keywords}

Uveal melanoma, GNAQ, GNA11, mitogen activated protein kinase (MAPK) pathway, hepatic directed therapy, immunotherapy, CTLA-4, PD-1, MEK

Disclosures: April Salama has received research funding from BMS, Celldex, Genentech, Immunocore, Merck, Reata; and has served as Consultant/Advisory to BMS. Emily N Kinsey has nothing to disclose in relation to this article. No funding was received in the publication of this article.

Compliance with Ethics: This study involves a review of the literature and did not involve any studies with human or animal subjects performed by any of the authors.

Authorship: All named authors meet the International Committee of Medical Journal Editors (ICMJE) criteria for authorship of this manuscript, take responsibility for the integrity of the work as a whole, and have given final approval to the version to be published.

Open Access: This article is published under the creative commons Attribution Noncommercial License, which permits any non-commercial use, distribution, adaptation and reproduction provided the original author(s) and source are given appropriate credit.

Received: June 5, 2017

Accepted: July 26, 2017

Citation: Oncology \& Hematology Review, 2017;13(2):100-6

Corresponding Author: Emily N Kinsey, Medical Education Office, Duke Medical Center, 2301 Erwin Road, DN8254, Durham, NC 27710. E: Emily.Kinsey@dm.duke.edu
Ocular melanoma represents a small subset of total melanoma cases. Approximately $3.7 \%$ of melanoma cases are ocular, ${ }^{1}$ and slightly over $80 \%$ of ocular melanomas are classified as uveal., Most uveal melanomas occur from the choroid, with the remainder developing from the ciliary body or iris. ${ }^{1}$ The rate of ocular melanoma is $8-10$ times higher in white than black people, and it is slightly more common in men than women. ${ }^{1}$

The overall 5-year survival of uveal melanoma has been reported as high as $82 \%{ }^{2}$ however, survival drops off significantly once metastatic disease is present. The Collaborative Ocular Melanoma Study (COMS) Group found that the rates of metastatic disease at 5 and 10 years after diagnosis were 25\% and $34 \%$, respectively. ${ }^{3}$ The most common site of metastasis is the liver, with liver lesions present in 77-94\% of patients with metastatic disease..$^{3-6}$ Other common sites of metastasis include lung and bone. ${ }^{3,6}$ Once uveal melanoma metastasizes, the median survival is only 2 months without treatment. ${ }^{5}$ Even despite treatment, the median survival is still typically less than one year. ${ }^{3-5,7}$

The disheartening survival rates in metastatic disease underscore the importance of developing treatments for metastatic uveal melanoma. Chemotherapy regimens, similar to those used with cutaneous melanoma, have demonstrated dismal response rates between $0-6 \%$, and none have been shown to prolong overall survival. ${ }^{8-12}$ Because the liver is frequently the sole site of metastatic disease, hepatic-directed therapy is often considered. Advances in molecular biology have led to an understanding of distinct genetic differences between uveal and cutaneous melanoma, which highlight the need for distinct treatments. This review describes the current therapeutic options in the treatment of metastatic uveal melanoma.

\section{Molecular biology}

The mitogen activated protein kinase (MAPK) pathway plays a significant role in cutaneous and uveal melanoma through its effects on cell proliferation. In cutaneous melanoma, upstream mutations in BRAF and NRAS activate the MAPK pathway and affect cell division and apoptosis. ${ }^{13,14}$ BRAF and NRAS mutations are not typically found in uveal melanoma, but the MAPK pathway is constitutively activated nonetheless. ${ }^{15}$ Instead, the GNAQ and GNA11 genes encode the alpha subunit of G-proteins that become proto-oncogenes when mutated. These mutations activate the MAPK pathway, leading to uninhibited cell proliferation and contributing to the development of uveal melanoma..$^{16,17}$ Mutually exclusive mutations in GNAQ or GNA11 are seen in 83\% of uveal melanomas. ${ }^{15}$ The various signaling 
pathways that are potential therapeutic targets in uveal melanoma include the MAPK, protein kinase C (PKC), and phosphoinositide 3-kinase (PI3K)/ Akt/mammalian target of rapamycin (mTOR) pathways. ${ }^{18-22}$

Receptor tyrosine kinases c-kit and c-Met (MET) have also been implicated in the pathogenesis of uveal melanoma, promoting tumor development and metastasis. ${ }^{23-25}$ Overexpression of the chaperone protein heat shock protein 90 (Hsp90) alters the Akt pathway to inhibit cell death, and its presence is associated with a worse prognosis. ${ }^{26}$ Loss of the tumor suppressor BRCA Associated Protein 1 (BAP1) also portends a poor prognosis and is highly associated with metastatic disease. ${ }^{27}$

\section{Hepatic-directed therapy}

In contrast to cutaneous disease, the development of metastases in uveal melanoma often follows a predictable pattern with the liver as the most common site of tumor spread. ${ }^{3-6}$ In many patients with metastatic disease, the liver is the only site of metastatic disease and is often the driver of morbidity and mortality., ${ }^{4,2}$

\section{Surgery}

Patients with limited sites of disease should undergo evaluation by a multidisciplinary team for consideration of metastasectomy. Surgical resection of liver lesions has been shown to improve overall survival in several observational studies in highly selected patients. A major limitation however, is that the vast majority of patients with metastatic uveal melanoma will not qualify for surgical resection due to the number or distribution of lesions. ${ }^{29}$ In one retrospective study including 255 patients who underwent surgical resection, the median overall survival was 14 months. ${ }^{30}$ Survival directly correlated with the surgical margin status. In patients who had an Ro resection, the overall survival was 27 months. ${ }^{30}$ Of the few patients who qualify for surgery, only 30-37\% of them will undergo an R0 resection. ${ }^{30,31}$ Other prognostic factors to consider include the number of lesions present in the liver, with a smaller number of lesions predicting a better response to surgical resection. ${ }^{28,30,31}$

\section{Radiofrequency ablation}

Because many patients with liver metastases will not qualify for surgical resection, radiofrequency ablation (RFA) has been investigated as an alternative option for poor surgical candidates with a small number of liver lesions. A retrospective study of 20 patients with liver metastases from melanoma found that overall survival in these patients was 19.3 months after treatment with RFA; however, patients with six or more metastatic liver lesions were excluded from the study. ${ }^{32}$ RFA may be a potential therapeutic option in the future, but further studies are needed to determine efficacy of this treatment.

\section{Direct therapy}

The dual blood supply to the liver presents a unique opportunity for delivering therapy directly to liver metastases since liver tumors are almost exclusively supplied by the hepatic artery. ${ }^{33}$ Various techniques utilize the dual blood supply of the liver to preferentially deliver chemotherapy, radiotherapy, or immune therapy to the tumors while minimizing effects on the normal hepatic parenchyma. Large doses of chemotherapy can be delivered through the hepatic artery to achieve high concentrations in the liver while mitigating systemic side effects. Direct therapies have not prolonged overall survival but have shown modest benefit in selected subsets of patients. Future studies are needed before these therapies can be universally recommended.

\section{Hepatic perfusion}

The delivery of melphalan chloride to the liver via a surgical or a percutaneous approach has also demonstrated some potential for disease control. Isolated hepatic perfusion (IHP) is an open surgical technique that allows chemotherapy to be delivered to the liver while it is temporarily sequestered from the systemic circulation. The surgeon isolates the liver from the systemic circulation by clamping inflow arteries and outflow veins. Once the liver is isolated, high doses of chemotherapy are delivered to the liver with an extracorporeal perfusion circuit. ${ }^{34,35} \mathrm{HHP}$ is associated with high response rates, ranging from $33-68 \%,{ }^{36-40}$ and a potential survival benefit of up to a year. ${ }^{37}$ Despite encouraging overall survival rates, ${ }^{36,38,40}$ this technique is not widely accepted due to lengthy procedure times, long hospitalizations, ${ }_{1}^{27}$ the morbidity associated with the procedure, ${ }_{1}^{36,40}$ and its inability to be repeated. ${ }^{35,40} \mathrm{~A}$ phase III trial comparing IHP to best alternative care is ongoing (NCT01785316).

For patients who are poor surgical candidates or who may need repeated procedures, a percutaneous alternative to IHP is available. Percutaneous hepatic perfusion (PHP) utilizes a double-balloon catheter to block the hepatic venous outflow while melphalan is delivered through a catheter in the hepatic artery. In both IHP and PHP, the systemic circulation is maintained through a venoveno bypass circuit while the procedure is taking place. Phase I trials demonstrated the safety and feasibility of PHP. ${ }^{41}$ A recent phase III trial that compared PHP to best alternative care found statistically significant differences in hepatic progression free survival (7.0 versus 1.6 months), overall progression free survival (5.4 versus 1.6 months), and hepatic objective response (36.4\% versus $2.0 \%$ ). The advantage in overall survival did not reach statistical significance possibly due to the high crossover rate. ${ }^{42} \mathrm{~A}$ second phase III trial comparing PHP to one of four best alternative care options is currently recruiting participants (NCT02678572)

\section{Chemoembolization}

Transarterial chemoembolization (TACE) delivers high concentrations of chemotherapy to the liver while also restricting blood supply and inducing ischemia of the tumor. The procedure is well tolerated, decreases systemic side effects, limits washout of chemotherapy, and can be repeated multiple times in the same patient. ${ }^{43,44}$ Favorable clinical benefit rates have been shown in small studies.44,45 Typically, patients with less liver involvement have a greater survival benefit. ${ }^{44-46}$ Once liver involvement is greater than $50 \%$, no difference in survival is seen. ${ }^{47}$ Patients with nodular disease had longer progression free survival and overall survival compared to those with diffuse liver involvement. ${ }^{48}$ At present, only limited data are available regarding optimal hepatic directed therapies, a clinical trial is currently recruiting participants to compare TACE to radioembolization in patients with metastatic uveal melanoma (NCT02936388).

\section{Immunoembolization}

Like chemoembolization, immunoembolization (IE) can deliver treatment preferentially to liver metastases via the hepatic artery. Instead of delivering chemotherapy, IE delivers granulocyte macrophage colonystimulating factor (GM-CSF) to stimulate the immune system to target tumor specific antigens. A phase I clinical trial in patients with uveal melanoma found a 32\% radiographic response rate with immunotherapy, and a higher GM-CSF dose (>1500 ug) was associated with prolonged survival. ${ }^{99} \mathrm{~A}$ retrospective study of 53 patients showed that high dose IE resulted in longer overall survival than chemoembolization. ${ }^{50}$ In the subset 
Table 1: Selected hepatic-directed therapy studies

\begin{tabular}{|c|c|c|c|c|}
\hline Study & Trial design & Agents studied & $\mathrm{N}$ & $\begin{array}{l}\text { OS } \\
\text { (months) }\end{array}$ \\
\hline \multirow{4}{*}{$\begin{array}{l}\text { Mariani } \\
\text { et al. }{ }^{30}\end{array}$} & \multirow[t]{4}{*}{ Retrospective } & Surgery & 255 & 14 \\
\hline & & R0 Resection & 76 & 27 \\
\hline & & R1 Resection & 22 & 17 \\
\hline & & R2 Resection & 157 & 11 \\
\hline $\begin{array}{l}\text { Van lersel } \\
\text { et al. }{ }^{36}\end{array}$ & Prospective & IHP with Melphalan & 13 & 10 \\
\hline $\operatorname{Vog}^{43}$ & Prospective & TACE with Mitomycin & 12 & 21 \\
\hline Huppert ${ }^{44}$ & Prospective & TACE with cisplatin or carboplatin & 14 & 11.5 \\
\hline \multirow[t]{4}{*}{ Patel $^{46}$} & \multirow[t]{4}{*}{ Phase II trial } & Chemoembolization with BCNU & 24 & 5.2 \\
\hline & & Patients with CR or PR & 5 & 21.9 \\
\hline & & Patients with SD & 13 & 8 \\
\hline & & Patients with PD disease & 6 & 3.3 \\
\hline Gonsalves $^{47}$ & Prospective & Chemoembolization with BCNU & 50 & 7.1 \\
\hline \multirow[t]{4}{*}{ Yamamoto $^{50}$} & \multirow[t]{4}{*}{ Retrospective } & Chemoembolization with $\mathrm{BCNU}$ & 19 & 9.8 \\
\hline & & IE with GM-CSF & 34 & NC \\
\hline & & High dose GM-CSF & 16 & 20.4 \\
\hline & & Low dose GM-CSF & 18 & $13(p=0.10)$ \\
\hline \multirow[t]{2}{*}{ Valsecchis1 } & \multirow[t]{2}{*}{ Phase II trial } & IE with high dose GM-CSF & 25 & 21.5 \\
\hline & & Bland embolization & 27 & 17.2 \\
\hline Eldredge $^{53}$ & Retrospective & Radioembolization with ${ }^{90} \mathrm{Y}$ & 71 & 12.3 \\
\hline
\end{tabular}

$B C N U=1,3$-bis(2-chloroethyl)-1-nitrosourea; $C R=$ complete response; $G M$-CSF = granulocyte macrophage colony-stimulating factor; IE = immunoembolization;

$I H P=$ isolated hepatic perfusion; $N C=$ not calculated $P D=$ progressive disease:

$P R=$ partial response; $R O=$ microscopically complete; $R 1=$ microscopically

incomplete; $R 2$ = macroscopically incomplete; $S D$ = stable disease;

TACE $=$ transarterial chemoembolization: ${ }^{90} \mathrm{Y}=$ Yttrium-90

of patients with $>20-50 \%$ of liver involvement by tumor, IE is favored over bland embolization as well.51,52 No randomized trials comparing chemoembolization and IE have been completed, and IE is not widely performed outside of selected centers.

\section{Radioembolization}

Radioembolization can utilize the liver's dual blood supply to deliver radiation preferentially to liver metastases. A beta-emitting isotope Yttrium-90 $\left.{ }^{\circ 0} \mathrm{Y}\right)$ is encapsulated in microspheres with an average penetration of ${ }^{\circ 0} \mathrm{Y}$ is $2.5 \mathrm{~mm}$, so radiation induced liver injury is uncommon. ${ }^{90} \mathrm{Y}$ has been used in metastatic disease to the liver for many years, but no clinical trials involving uveal melanoma have been completed. Retrospective studies of metastatic uveal melanoma treated with radioembolization have demonstrated median overall survival rates from 7 months to over 1 year after treatment. ${ }^{53-55}$ Further data is needed before radioembolization can be widely adopted, and a phase I/II study to evaluate for synergy between radioembolization and immunotherapy is currently underway (NCT02913417). See Table 1 for selected hepatic-directed therapy studies.

\section{Systemic therapy}

Contrary to hepatic-directed treatments, systemic therapies have the ability to treat tumor cells throughout the body, including microscopic disease. Conventional systemic chemotherapy, however, has shown poor response rates in uveal melanoma..$^{-12} \mathrm{~A}$ number of genes and intracellular signaling pathways play important roles in the pathogenesis of uveal melanoma, the development of metastases, and the aggressive nature of this cancer. An increased understanding of the molecular genetics and intracellular signaling of uveal melanoma has led to the development of immunotherapy and targeted systemic therapies.

\section{CTLA inhibition}

Targeting the cytotoxic $\mathrm{T}$ lymphocyte associated antigen-4 (CTLA-4) receptor by ipilimumab is a treatment option for patients with metastatic cutaneous melanoma. A pooled analysis of survival data from 1,861 patients revealed $22 \%$ of patients survived to at least 3 years, at which time the survival curve plateaued. In some studies patients were followed almost 10 years, demonstrating the durability of response to treatment. ${ }^{56}$ Definitive prospective data in uveal melanoma is lacking, as these patients were excluded from the initial phase III trials. ${ }^{57,58}$ One prospective study to determine safety and efficacy of ipilimumab evaluated 82 patients with stage IV uveal melanoma who had failed prior systemic therapy. This study showed an immune-related objective response rate in $5 \%$, immunerelated stable disease in 29\%, and median overall survival of 6 months. ${ }^{59}$ When only analyzing the subset of patients with baseline lactate dehydrogenase values $<480 \mathrm{U} / \mathrm{l}$, the overall survival increased to 11.6 months. Smaller studies have shown conflicting results with rates of stable disease ranging from 0-44\%, and overall survival ranging from 5.2-9.6 months; however, some of these studies had as few as 13 patients and others were retrospective. ${ }^{60-62}$

The DeCOG trial, a multicenter, single-arm, phase II clinical trial evaluated ipilimumab in patients with metastatic uveal melanoma, is the only published phase II clinical trial to date. The median overall survival was 6.8 months with stable disease in $47 \%$. The 2-year survival rate was only $7 \%$, and they concluded that ipilimumab has limited activity in patients with metastatic uveal melanoma. ${ }^{63}$ Preliminary results from a phase II trial conducted in Spain showed more promising results. At 5.5 months $7.7 \%$ had a partial response and $46.2 \%$ had stable disease; however, the overall survival and progression free survival results are still pending. ${ }^{64}$ Outside of a clinical trial, ipilimumab therapy is a reasonable standard of care treatment option for patients with metastatic uveal melanoma.

\section{PD-1 inhibitors}

Pembrolizumab and nivolumab are programmed cell death-1 (PD-1) receptor antibodies approved for the treatment of metastatic melanoma. Compared to ipilimumab, pembrolizumab improved survival, response rates, and had fewer treatment-related adverse events in patients with cutaneous melanoma. ${ }^{65}$ However, a multicenter retrospective review of patients with metastatic uveal melanoma who had received either a PD-1 or programmed death-ligand 1 (PD-L1) antibody inhibitor, demonstrated that these medications are well tolerated, but the response rates were less promising. The overall response rate was only $3.6 \%$ with a median progression free survival of 2.6 months and median overall survival of 7.6 months. $^{66}$ The poor response to these agents is likely due to the very low rates of PD-1 and PD-L1 expression in uveal melanoma. ${ }^{67} \mathrm{~A}$ phase ॥ trial evaluating the safety and efficacy of pembrolizumab in patients with metastatic uveal melanoma is currently recruiting patients (NCT02359851).

\section{Novel immune therapies}

Tumor cells evade the immune system by a number of mechanisms, one of which is inducing dysfunction of dendritic cells. ${ }^{68}$ As a way to enhance immunogenicity of vaccines, dendritic cells can be incorporated as vectors 


\begin{tabular}{|c|c|c|c|c|c|}
\hline Study & Trial design & Patient population & Agents studied & $\mathrm{N}$ & $\begin{array}{l}\text { OS months } \\
\text { (\% } 1 \text { year OS) }\end{array}$ \\
\hline \multirow[t]{3}{*}{ Maio et al. ${ }^{59}$} & \multirow[t]{3}{*}{$\begin{array}{l}\text { Prospective; expanded } \\
\text { access program }\end{array}$} & \multirow[t]{3}{*}{$\begin{array}{l}\text { Failed systemic therapy, intolerant to systemic therapy, } \\
\text { or no alternative treatments available }\end{array}$} & $\begin{array}{l}\text { Ipilimumab } 3 \mathrm{mg} / \mathrm{kg} \text { every } 3 \text { weeks for } \\
\text { four doses }\end{array}$ & 82 & $6.0(31 \%)$ \\
\hline & & & Baseline $\mathrm{LDH}<480 \mathrm{U} / \mathrm{I}$ & 40 & 11.6 \\
\hline & & & Baseline LDH $\geq 480 \mathrm{U} / \mathrm{I}$ & 33 & 3.0 \\
\hline \multirow[t]{3}{*}{ Luke et al..$^{60}$} & \multirow[t]{3}{*}{ Retrospective } & \multirow{3}{*}{$\begin{array}{l}\text { Ipilimumab monotherapy; excluded ipilimumab in } \\
\text { combination with other agents or as re-induction therapy }\end{array}$} & Ipilimumab 3 mg/kg or 10 mg/kg & 39 & 9.6 \\
\hline & & & ALC at week $7 \geq 1,000 \mathrm{ug} / \mathrm{L}$ & 22 & 13.4 \\
\hline & & & ALC at week $7<1,000 \mathrm{ug} / \mathrm{L}$ & 9 & 4.8 \\
\hline \multirow[t]{5}{*}{ Zimmer et al. ${ }^{63}$} & \multirow[t]{5}{*}{ Phase II; single arm } & \multirow[t]{5}{*}{ Pretreated and treatment-naïve } & Ipilimumab 3 mg/kg & 53 & $6.8(22 \%)$ \\
\hline & & & Baseline LDH $<2$ times ULN & 33 & $9.3(33 \%)$ \\
\hline & & & Baseline $\mathrm{LDH} \geq 2$ times ULN & 20 & $2.5(5 \%)$ \\
\hline & & & ALC at week $7 \geq 1,000 \mathrm{ug} / \mathrm{L}$ & $N R^{d}$ & $8.6(35 \%)$ \\
\hline & & & ALC at week $7<1,000 \mathrm{ug} / \mathrm{L}$ & NR & $3.1(0 \%)$ \\
\hline \multirow[t]{5}{*}{ Algazi et al. ${ }^{66}$} & \multirow[t]{5}{*}{ Retrospective } & \multirow[t]{5}{*}{ Pretreated and treatment-naïve } & PD-1 or PD-L1 antibody & 56 & 7.7 \\
\hline & & & Women & 24 & 13.3 \\
\hline & & & Men & 32 & 5.0 \\
\hline & & & Baseline LDH normal & 13 & 25.0 \\
\hline & & & Baseline LDH elevated & 40 & 5.2 \\
\hline \multirow[t]{2}{*}{ Carvajal et al. ${ }^{72}$} & \multirow[t]{2}{*}{ Phase Il; randomized } & \multirow{2}{*}{$\begin{array}{l}\text { Pretreated and treatment-naiive; excluded prior therapy } \\
\text { with MEK inhibitor, temozolomide, or DTIC }\end{array}$} & Selumetinib (MEK1/2 inhibitor) & 50 & $11.8, p>0.05$ \\
\hline & & & Chemotherapy (temozolomide or DTIC) & 51 & 9.1, $p>0.05$ \\
\hline
\end{tabular}

$A L C=$ absolute lymphocyte count; $D T I C=$ dacarbazine; $L D H=$ lactate dehydrogenase; $N R=$ not reported; $P D-1=$ programmed cell death receptor 1; $P D-L 1=$ programmed death ligand 1 ; ULN = upper limit of normal.

of melanoma-associated antigens (NCT00089219, NCT00313508). A small study of 14 patients with metastatic uveal melanoma evaluated the safety, immunologic response, and overall survival of patients treated with dendritic cell vaccination using gp100 and tyrosinase antigens. The patients exhibited no grade 3 or 4 adverse events. The overall survival was 19.2 months and $29 \%$ of patients demonstrated tumor-specific immune response. ${ }^{69}$

Immune mobilizing monoclonal T-cell receptors against cancer (ImmTACS) enable a patient's immune system to target tumor cells via a bidirectional biologic drug, IMCgp100. The drug binds the gp100 antigen on melanoma tumor cells while simultaneously binding and activating the patient's T cells. Preliminary data from a phase I trial demonstrated a favorable safety and response profile in cutaneous and uveal melanoma with a clinical benefit rate of $71 \%$. Of the fourteen evaluable uveal melanoma patients, two patients had a partial response (14\%) and eight patients had stable disease (57\%). ${ }^{70}$ Because of these results, IMCgp100 was granted orphan designation for the treatment of uveal melanoma, and phase I trials are ongoing (NCT01211262, NCT02570308).

\section{Targeted therapy}

GNAQ and GNA11 mutations affect cell proliferation and apoptosis through activation of the MAPK pathway and downstream effectors including the MEK, PKC, PI3K/AKt/mTOR signaling cascades. Activating mutations of the receptor tyrosine kinase c-kit, an upstream effector, have been implicated in uveal melanoma as well as other cancers. The inhibition of these signaling pathways is a potential rational treatment technique for metastatic uveal melanoma. Currently, these therapies are still considered investigational, and patients can gain access to targeted therapies through clinical trials.

\section{MEK inhibitors}

The clinical activity of the MEK inhibitor trametinib (GSK1120212) was evaluated in a phase I trial of patients with solid tumors, which included 16 patients with uveal melanoma, with encouraging results. Of the uveal melanoma patients, eight (50\%) had stable disease and four (25\%) maintained a durable response of at least sixteen weeks. ${ }^{71}$

The response rate to the MEK $1 / 2$ inhibitor selumetinib was markedly better when compared to chemotherapy in a phase II trial of uveal melanoma patients. In the selumetinib group, $49 \%$ of patients demonstrated tumor regression. Tumor regression was not seen in any of the patients in the chemotherapy group. Median progression-free survival was modestly improved with selumetinib compared to chemotherapy (15.9 weeks versus 7.0 weeks, respectively). The improvement in overall survival with selumetinib did not reach statistical significance (9.1 months, 95\% confidence interval [Cl] 6.1-11.1 for chemotherapy versus 11.8 months, 95\% Cl 9.8-15.7 for selumetinib); however, the study design allowed patients to receive selumetinib after progression on chemotherapy, which may have confounded the survival data. ${ }^{72}$ The only phase III trial involving a MEK inhibitor in uveal melanoma compared a MEK inhibitor and dacarbazine to dacarbazine alone, and it did not reach the primary endpoint of an improvement in progression free survival. The data analysis for this trial is still ongoing. ${ }^{73}$

Conflicting adverse event rates for MEK inhibitors have been reported. A phase I dose-escalation study of an oral MEK inhibitor (TAK-733) demonstrated a tolerable safety profile with only $14 \%$ of patients experiencing dose-limiting toxicities. ${ }^{74}$ However, the phase II trial mentioned above evaluated the oral MEK inhibitor selumetinib in uveal melanoma 
Table 3: Selected ongoing studies in metastatic uveal melanoma

\begin{tabular}{|c|c|c|c|c|}
\hline Intervention & Study population & Status & Design & Clinical trials ID \\
\hline $\begin{array}{l}\text { Transarterial radioembolization with }{ }^{90} \mathrm{Y} \\
\text { versus TACE with cisplatin }\end{array}$ & $\begin{array}{l}\text { Uveal melanoma with liver metastases; other metastatic } \\
\text { sites not needing treatment }\end{array}$ & Recruiting & $\begin{array}{l}\text { Phase II; randomized; parallel } \\
\text { assignment }\end{array}$ & NCT02936388 \\
\hline${ }^{90} \mathrm{Y}$, ipilimumab, nivolumab & $\begin{array}{l}\text { Uveal melanoma with liver metastases; exclude if prior } \\
\text { anti-CTLA-4 or anti-PD-1/PD-L1 therapy or if } \geq 1 \text { prior } \\
\text { systemic therapy }\end{array}$ & Recruiting & $\begin{array}{l}\text { Phase I/II; sequential therapy; } \\
\text { single group assignment }\end{array}$ & NCT02913417 \\
\hline $\begin{array}{l}\text { Isolated hepatic perfusion versus best } \\
\text { alternative care }\end{array}$ & $\begin{array}{l}\text { Uveal melanoma with liver metastases; treatment naïve } \\
\text { only }\end{array}$ & Recruiting & $\begin{array}{l}\text { Phase III; randomized; parallel } \\
\text { assignment }\end{array}$ & NCT01785316 \\
\hline $\begin{array}{l}\text { Trametinib (MEK inhibitor) +/- GSK2141795 } \\
\text { (Akt inhibitor) }\end{array}$ & $\begin{array}{l}\text { Metastatic uveal melanoma; exclude if prior systemic or } \\
\text { hepatic directed infusional/embolization therapies }\end{array}$ & $\begin{array}{l}\text { Ongoing, but } \\
\text { not recruiting }\end{array}$ & $\begin{array}{l}\text { Phase II; randomized; parallel } \\
\text { assignment }\end{array}$ & NCT01979523 \\
\hline Nivolumab and ipilimumab & $\begin{array}{l}\text { Uveal melanoma with metastatic lesions } \geq 1 \times 1 \mathrm{~cm} \text {; } \\
\text { exclude if metastatic disease is only to bone; pretreated } \\
\text { or treatment-naïve }\end{array}$ & Recruiting & $\begin{array}{l}\text { Phase II; single group } \\
\text { assignment }\end{array}$ & NCT01585194 \\
\hline IMCgp100 & $\begin{array}{l}\text { Metastatic uveal melanoma in patients who are HLA-A2 } \\
\text { positive; pretreated or treatment-naïve }\end{array}$ & Recruiting & $\begin{array}{l}\text { Phase I; single group } \\
\text { assignment }\end{array}$ & NCT02570308 \\
\hline Pembrolizumab + entinostat (HDAC inhibitor) & $\begin{array}{l}\text { Uveal melanoma with measurable disease based on } \\
\text { RECIST; exclude if prior immunotherapy }\end{array}$ & $\begin{array}{l}\text { Not yet } \\
\text { recruiting }\end{array}$ & $\begin{array}{l}\text { Phase II; single group } \\
\text { assignment }\end{array}$ & NCT02697630 \\
\hline $\begin{array}{l}\text { Chemotherapy and tumor-infiltrating } \\
\text { lymphocytes +/- high dose aldesleukin (IL-2) }\end{array}$ & $\begin{array}{l}\text { Metastatic ocular melanoma; Pretreated or treatment- } \\
\text { naïve }\end{array}$ & $\begin{array}{l}\text { Ongoing, but } \\
\text { not recruiting }\end{array}$ & $\begin{array}{l}\text { Phase II; non-randomized; } \\
\text { parallel assignment }\end{array}$ & NCT01814046 \\
\hline $\begin{array}{l}\text { Adoptive T cell therapy +/- } \\
\text { cyclophosphamide, IL-2, and ipilimumab }\end{array}$ & $\begin{array}{l}\text { Uveal melanoma with liver metastases; Pretreated or } \\
\text { treatment-naïve }\end{array}$ & $\begin{array}{l}\text { Not yet } \\
\text { recruiting }\end{array}$ & $\begin{array}{l}\text { Phase l; non-randomized; } \\
\text { parallel assignment }\end{array}$ & NCT03068624 \\
\hline
\end{tabular}

CTLA-4 = cytotoxic T-Iymphocyte protein 4 precursor: HDAC = histone deacetylase; $H L A=$ human leukocyte antigens; IL-2 = interleukin-2; PD-1 = programmed cell death receptor 1 ; $P D-L 1=$ programmed death ligand; RECIST $=$ Response Evaluation Criteria In Solid Tumors; TACE = transarterial chemoembolization; ${ }^{90} Y=Y$ ttrium-90.

patients and revealed an adverse event rate of $97 \%$ with dose-reduction required in $37 \% .^{72}$ Further studies are necessary to determine the safety and efficacy of these drugs.

\section{Other targets}

Sorafenib is a multikinase inhibitor targeting vascular endothelial growth factor (VEGF), platelet derived growth factor receptor, and the RAF family kinases. Sorafenib prolongs overall survival in advanced hepatocellular carcinoma and is currently the only systemic therapy approved for the treatment of metastatic hepatocellular carcinoma. ${ }^{75}$ Results from the first phase II trial evaluating sorafenib as a single agent in metastatic uveal melanoma were recently published, and the primary endpoint was nonprogression rate. Ten of 32 patients (31.2\%) showed non-progression at 24 weeks. ${ }^{76}$ The estimated overall survival was $62.5 \%$, but $41.4 \%$ of patients required dose adjustments due to serious adverse events. ${ }^{76} \mathrm{~A}$ phase II trial studying sorafenib in combination with chemotherapy has been completed, but the results are not yet available (NCT00329641). A phase II efficacy study of sorafenib versus placebo in chemonaive patients with metastatic uveal melanoma is ongoing in Germany (NCT01377025).

Another receptor tyrosine kinase inhibitor that is currently undergoing investigation is cabozantinib (XL184), which has multiple targets, though thought to primarily inhibit C-MET and VEGFR2. A phase ॥ randomized discontinuation trial of cabozantinib in patients with nine different types of advanced, recurrent, or metastatic solid tumors been completed, but full results are not yet published (NCT00940225). Results from the uveal melanoma subgroup showed activity of cabozantinib in these patients. Of the 23 patients with uveal melanoma, the median overall survival was 12.6 months and the median progression free survival was 4.8 months. ${ }^{77}$ A phase II trial comparing cabozantinib-s-malate to temozolomide or dacarbazine was recently halted, and results are not yet available (NCT01835145).

\section{Combination therapies}

Inhibiting multiple pathways could lead to a more robust response than is seen with monotherapy. Preclinical studies in vitro and in mouse models have demonstrated that combined inhibition therapy can promote synergy ${ }^{18-20,78-80}$ Initial clinical studies have not been confirmatory, however.

Simultaneously inhibiting both MEK and Akt, reduced cell viability in a synergistic manner, in preclinical GNAQ-mutant uveal melanoma mouse models. ${ }^{78}$ Consequently, this combination of therapies is currently being evaluated in a phase II study. ${ }^{81}$ Unfortunately, preliminary results from this trial did not show any improvement in progression free survival with combination MEK and Akt inhibitor therapy compared to monotherapy with a MEK inhibitor alone. ${ }^{81}$ Adverse events were found in $100 \%$ of patients, and the combination therapy arm had more grade 3 adverse events. Neither arm had grade 4 or 5 adverse events, but a dose reduction was required in seven of 18 patients using a MEK inhibitor alone and in seven of 21 patients using both MEK and Akt inhibitors in combination. This trial is still recruiting participants (NCT01979523). See Table 2 for selected trials on systemic therapy.

\section{Future directions}

Clinical trials to evaluate multiple targeted therapies and therefore the inhibition of multiple pathways simultaneously, are currently underway. Furthermore, combination therapy with diverse groupings of targeted therapy, immune therapy, chemotherapy, and hepatic-directed therapies are under investigation at various stages.

Adoptive cell therapy has shown promising results in cutaneous melanoma, but has not yet been studied extensively in uveal melanoma. This approach infuses tumor specific $T$ cells into a patient with the aim of immune recognition and destruction of tumor cells. ${ }^{82} \mathrm{~A}$ phase $\|$ trial is currently 
ongoing to study the safety and efficacy of the infusion of autologous tumor-infiltrating lymphocytes in patients with metastatic uveal melanoma (NCT01814046).

Other novel therapeutics are also being investigated. Glembatumumab vedotin is an antibody-drug conjugate, which combines an antibody directed at the transmembrane glycoprotein NMB (gpNMB) with the microtubule inhibitor monomethyl auristatin (MMAE). Modest clinical activity has been demonstrated in heavily pretreated cutaneous melanoma patients. ${ }^{83}$ Given the high frequency of gpNMB expression in uveal melanoma, there is a strong preclinical rationale to explore the antitumor activity in this patient population. ${ }^{84} \mathrm{~A}$ phase II study evaluating glembatumumab vedotin in patients with uveal melanoma has recently completed accrual (NCT02363283).

The epigenetics of cancer is another therapeutic approach under investigation. Enzymes such as DNA methyltransferases and histone deacetylases are potential targets as they can impact gene expression as well as cell proliferation and differentiation. Preclinical data suggests that histone deacetylase inhibitors could change the aggressive phenotype of uveal melanoma cells in vitro. ${ }^{85} \mathrm{~A}$ phase $\|$ trial evaluating vorinostat, a histone deacetylase inhibitor, in metastatic uveal melanoma is underway (NCT01587352). The combination of a histone deacetylase inhibitor and pembrolizumab is also currently under investigation in a phase II trial (NCT02697630). See Table 3 for selected ongoing studies.

\section{Conclusion}

Metastatic uveal melanoma has a grim prognosis, and currently no standard of care exists to guide management. The molecular profile of uveal melanoma is distinct from cutaneous melanoma, and accordingly the treatments differ. In order to define optimal management, patients diagnosed with advanced uveal melanoma should be offered participation in a clinical trial whenever possible. Advances in knowledge of the genetic/ immunologic profile of uveal melanoma have led to the development of novel treatments that are currently under investigation. Future therapies will likely involve an integrated approach, using a combination of treatment modalities. $]$
1. McLaughlin CC, Wu XC, Jemal A, et al., Incidence of noncutaneous melanomas in the U.S. Cancer, 2005:103:1000-7.

2. Singh $A D$, Turell $M E$, Topham $A K$, Uveal melanoma: trends in incidence, treatment, and survival, Ophthalmology, 2011:118:1881-5.

3. Diener-West M, Reynolds SM, Agugliaro DJ, et al., Development of metastatic disease after enrollment in the COMS trials for treatment of choroidal melanoma: Collaborative Ocula Melanoma Study Group Report No. 26, Arch Ophthalmol, 2005;123:1639-43.

4. Rietschel P, Panageas KS, Hanlon C, et al., Variates of survival in metastatic uveal melanoma, J Clin Oncol, 2005:23:8076-80.

5. Gragoudas ES, Egan KM, Seddon JM, et al., Survival of patients with metastases from uveal melanoma, Ophthalmology, 1991;98:383-9; discussion 90

6. Collaborative Ocular Melanoma Study G. Assessment of metastatic disease status at death in 435 patients with large choroidal melanoma in the Collaborative Ocular Melanoma Study (COMS): COMS report no. 15, Arch Ophthalmol, 2001;119:670-6.

Kath R, Hayungs J, Bornfeld N, et al., Prognosis and treatment of disseminated uveal melanoma, Cancer, 1993:72:2219-23.

8. Schmittel A, Scheulen ME, Bechrakis NE, et al., Phase II trial of cisplatin, gemcitabine and treosulfan in patients with metastatic uveal melanoma, Melanoma Res, 2005;15:205-7.

9. O'Neill PA, Butt M, Eswar CV, et al., A prospective single arm phase II study of dacarbazine and treosulfan as first-line therapy in metastatic uveal melanoma, Melanoma Res, 2006:16:245-8.

10. Leyvraz S, Piperno-Neumann S, Suciu S, et al., Hepatic intraarterial versus intravenous fotemustine in patients with liver metastases from uveal melanoma (EORTC 18021): a multicentric metastases from uveal melanoma (EORTC

11. Kivela T, Suciu S, Hansson J, et al., Bleomycin, vincristine Iomustine and dacarbazine (BOLD) in combination with recombinant interferon alpha-2b for metastatic uveal melanoma Eur J Cancer, 2003;39:1115-20

12. Bedikian AY, Papadopoulos $N$, Plager $C$, et al, Phase II evaluation of temozolomide in metastatic choroidal melanoma, Melanoma Res, 2003:13:303-6.

13. van ' $t$ Veer $L$, Burgering $B M$, Versteeg $R$, et al., $N$-ras mutations in human cutaneous melanoma from sun-exposed body sites, $\mathrm{MO}$ Cell Biol, 1989;9:3114-6.

14. Davies $\mathrm{H}$, Bignell GR, Cox C, et al., Mutations of the BRAF gene in human cancer, Nature, 2002;417:949-54.

15. Zuidervaart $\mathrm{W}$, van Nieuwpoort $\mathrm{F}$, Stark $\mathrm{M}$, et al., Activation of the MAPK pathway is a common event in uveal melanomas althoug it rarely occurs through mutation of BRAF or RAS, Br $J$ Cancer, 2005:92:2032-8.

16. Van Raamsdonk CD, Griewank KG, Crosby MB, et al., Mutations in GNA11 in uveal melanoma, N Eng/ J Med, 2010;363:2191-9.

17. Van Raamsdonk CD, Bezrookove V, Green G, et al., Frequent somatic mutations of GNAQ in uveal melanoma and blue naevi, Nature, 2009;457:599-602.

18. Amirouchene-Angelozzi N, Frisch-Dit-Leitz E, Carita G, et al., The mTOR inhibitor Everolimus synergizes with the PI3K inhibitor GDC0941 to enhance anti-tumor efficacy in uveal melanoma, Oncotarget, 2016;7:23633-46.

19. Chen $X$, Wu $Q$, Tan L, et al., Combined PKC and MEK inhibition in uveal melanoma with GNAQ and GNA11 mutations, oncogene, 2014;33:4724-34

20. Ho AL, Musi E, Ambrosini G, et al., Impact of combined mTOR and MEK inhibition in uveal melanoma is driven by tumor genotype, PLOS One, 2012:7:e40439.

21. Sagoo MS, Harbour JW, Stebbing J, Bowcock AM, Combined PKC and MEK inhibition for treating metastatic uveal melanoma
Oncogene, 2014;33:4722-3.

22. Wu X, Zhu M, Fletcher JA, et al., The protein kinase $\mathrm{C}$ inhibitor enzastaurin exhibits antitumor activity against uveal melanoma, PLoS One, 2012;7:e29622

23. Mallikarjuna K, Pushparaj V, Biswas J, Krishnakumar S, Expression of epidermal growth factor receptor, ezrin, hepatocyte growth factor, and c-Met in uveal melanoma: an immunohistochemica study, Curr Eye Res, 2007;32:281-90

24. All-Ericsson C, Girnita L, Muller-Brunotte A, et al., C-Kit-dependent growth of uveal melanoma cells: a potential therapeutic target?, Invest Ophthalmol Vis Sci, 2004:45:2075-82.

25. Abdel-Rahman MH, Boru G, Massengill J, et al., MET oncogene inhibition as a potential target of therapy for uveal melanomas, Invest Ophthalmol Vis Sci, 2010;51:3333-9.

26. Faingold D, Marshall JC, Antecka E, et al., Immune expression and inhibition of heat shock protein 90 in uveal melanoma, Clin Cancer Res, 2008; 14:847-55

27. Harbour JW, Onken MD, Roberson ED, et al., Frequent mutation of BAP1 in metastasizing uveal melanomas, science, 2010;330:1410-3.

28. Akyuz M, Yazici P, Dural C, et al., Laparoscopic management of liver metastases from uveal melanoma, Surg Endosc, 2016;30:2567-71

29. Aoyama T, Mastrangelo MJ, Berd D, et al., Protracted surviva after resection of metastatic uveal melanoma, Cancer 2000;89:1561-8.

30. Mariani P, Piperno-Neumann S, Servois V, et al., Surgica management of liver metastases from uveal melanoma: 16 years experience at the Institut Curie, Eur I Surg Oncol 2009:35:1192-7.

31. Frenkel $S$, Nir I, Hendler $K$, et al., Long-term survival of uveal melanoma patients after surgery for liver metastases, $\mathrm{Br} J$ Ophthalmol, 2009;93:1042-6.

32. Bale R, Schullian P, Schmuth M, et al., Stereotactic radiofrequency ablation for metastatic melanoma to the liver, Cardiovasc Intervent Radiol, 2016;39:1128-35.

33. Breedis $\mathrm{C}$, Young $\mathrm{G}$, The blood supply of neoplasms in the liver, Am J Pathol, 1954:30:969-77.

34. Reddy SK, Kesmodel SB, Alexander HR, Jr, et al., Isolated hepatic perfusion for patients with liver metastases, Ther Adv Med Oncol, 2014;6:180-94

35. Facy O, Doussot A, Zinzindohoue F, et al., Isolated hepatic perfusion: principles and results, J Vasc Surg, 2014;151 Supp 1:S25-32

36. van Iersel LB, Hoekman EJ, Gelderblom H, et al., Isolated hepatic perfusion with $200 \mathrm{mg}$ melphalan for advanced noncolorectal liver metastases, Ann Surg Oncol, 2008:15:1891-8.

37. Olofsson R, Cahlin C, All-Ericsson C, et al., Isolated hepatic perfusion for ocular melanoma metastasis: registry data suggest a survival benefit, Ann Surg Oncol, 2014;21:466-72.

38. Noter SL, Rothbarth J, Pijl ME, et al., Isolated hepatic perfusion with high-dose melphalan for the treatment of uveal melanoma metastases confined to the liver, Melanoma Res, 2004:14:67-72.

39. Ben-Shabat I, Belgrano V, Ny L, Long-term follow-up evaluation of 68 patients with uveal melanoma liver metastases treated with isolated hepatic perfusion, Ann Surg Oncol, 2016;23:1327-34.

40. Alexander HR, Jr., Libutti SK, Pingpank JF, et al., Hyperthermic isolated hepatic perfusion using melphalan for patients with ocular melanoma metastatic to liver, Clin Cancer Res, 2003;9:6343-9.

41. Pingpank JF, Libutti SK, Chang R, et al., Phase I study of hepatic arterial melphalan infusion and hepatic venous hemofiltration using percutaneously placed catheters in patients with unresectable hepatic malignancies, J Clin Oncol,
2005;23:3465-74.

42. Hughes MS, Zager J, Faries M, et al., Results of a randomized controlled multicenter phase iii trial of percutaneous hepatic perfusion compared with best available care for patients with melanoma liver metastases, Ann Surg Oncol, 2016;23:1309-19.

43. Vogl T, Eichler $\mathrm{K}$, Zangos S, et al., Preliminary experience with transarterial chemoembolization (TACE) in liver metastases of uveal malignant melanoma: local tumor control and survival, J Cancer Res Clin Oncol, 2007:133:177-84.

44. Huppert PE, Fierlbeck G, Pereira P, et al., Transarterial chemoembolization of liver metastases in patients with uveal melanoma, Eur J Radiol, 2010;74:e38-44.

45. Fiorentini G, Aliberti C, Del Conte A, et al., Intra-arterial hepatic chemoembolization (TACE) of liver metastases from ocular melanoma with slow-release irinotecan-eluting beads. Early results of a phase II clinical study, In Vivo, 2009;23:131-7.

46. Patel K, Sullivan K, Berd D, et al., Chemoembolization of the hepatic artery with $\mathrm{BCNU}$ for metastatic uveal melanoma: results of a phase II study, Melanoma Res, 2005;15:297-304.

47 Gonsalves CF. Eschelman DJ, Thornburg B, et al., Uveal melanoma metastatic to the liver: chemoembolization with 1,3-bis-(2-chloroethyl)-1-nitrosourea, AJR Am J Roentgenol, 2015;205:429-33.

48. Sharma KV, Gould JE, Harbour JW, et al., Hepatic arteria chemoembolization for management of metastatic melanoma AJR Am J Roentgenol, 2008;190:99-104.

49. Sato T, Eschelman DJ, Gonsalves CF, et al., Immunoembolization of malignant liver tumors, including uveal melanoma, using granulocyte-macrophage colony-stimulating factor, $J$ Clin Oncol, 2008;26:5436-42.

50. Yamamoto A, Chervoneva I, Sullivan KL, et al., High-dose immunoembolization: survival benefit in patients with hepatic metastases from uveal melanoma, Radiology, 2009;252:290-8.

51. Valsecchi ME, Terai M, Eschelman DJ, et al., Double-blinded, randomized phase II study using embolization with or without granulocyte-macrophage colony-stimulating factor in uveal melanoma with hepatic metastases, J Vasc Interv Radiol, 2015:26:523-32.

52. Eschelman DJ, Gonsalves CF, Terai M, et al., The results of a randomized phase II study using embolization with or without granulocyte-macrophage colony-stimulating factor (GM-CSF) in uveal melanoma patients with hepatic metastasis, J Clin Oncol, 2011;29:8577

53. Eldredge-Hindy $\mathrm{H}$, Ohri $\mathrm{N}$, Anne PR, et al., Yttrium-90 microsphere brachytherapy for liver metastases from uveal melanoma: clinical outcomes and the predictive value of fluorodeoxyglucose positron emission tomography, Am J Clin Oncol, 2016;39:189-95.

54. Kennedy AS, Nutting C, Jakobs T, et al., A first report of radioembolization for hepatic metastases from ocular melanoma Cancer Invest, 2009;27:682-90

55. Klingenstein A, Haug AR, Zech CJ, Schaller UC, Radioembolization as locoregional therapy of hepatic metastases in uveal melanoma patients, Cardiovasc Intervent Radiol, 2013:36:158-65.

56. Schadendorf D, Hodi FS, Robert $C$, et al., Pooled analysis of long-term survival data from phase II and phase III trials of ipilimumab in unresectable or metastatic melanoma, J Clin oncol, 2015;33:1889-94.

57. Maio M, Grob JJ, Aamdal S, et al., Five-year survival rates for treatment-naive patients with advanced melanoma who received ipilimumab plus dacarbazine in a phase III trial, I Clin Oncol, 2015;33:1191-6.

58. Hodi FS, O'Day SJ, MCDermott DF, et al., Improved survival with ipilimumab in patients with metastatic melanoma, N Engl I Med, 
2010;363:711-23

59. Maio M, Danielli R, Chiarion-Sileni V, et al., Efficacy and safety of ipilimumab in patients with pre-treated, uveal melanoma, Ann Oncol, 2013;24:2911-5.

60. Luke JJ, Callahan MK, Postow MA, et al., Clinical activity of ipilimumab for metastatic uveal melanoma: a retrospective review of the Dana-Farber Cancer Institute, Massachusetts General Hospital, Memorial Sloan-Kettering Cancer Center, and University Hospital of Lausanne experience, Cancer 2013;119:3687-95.

61. Kelderman S, van der Kooij MK, van den Eertwegh AJ, et al., Ipilimumab in pretreated metastastic uveal melanoma patients. Results of the Dutch Working group on Immunotherapy of Oncology (WIN-O), Acta Oncol, 2013;52:1786-8.

62. Danielli R, Ridolfi R, Chiarion-Sileni V et al., Ipilimumab in pretreated patients with metastatic uveal melanoma: safety and clinical efficacy, Cancer Immunol Immunother 2012;61:41-8.

63. Zimmer L, Vaubel J, Mohr P, et al., Phase II DeCoG-study of ipilimumab in pretreated and treatment-naive patients with metastatic uveal melanoma, PLoS One, 2015:10:e0118564.

64. Rodriguez JMP, de Olza MO, Codes M, et al., Phase II study evaluating ipilimumab as a single agent in the first-line treatment of adult patients (Pts) with metastatic uveal melanoma (MUM) The GEM-1 trial, J Clin Oncol, 2014;32(abstr):9033.

65. Robert C, Schachter J, Long GV, et al., Pembrolizumab versus Ipilimumab in Advanced Melanoma, N Eng/ I Med, 2015;372:2521-32.

66. Algazi AP, Tsai KK, Shoushtari AN, et al., Clinical outcomes in metastatic uveal melanoma treated with PD-1 and PD-L1 In metastatic uveal melanoma treated
antibodies, Cancer, 2016:122:3344-53.

67. Javed A, Arguello D, Johnston C, et al., Disparity in PD-L1 expression between metastatic uveal and cutaneous melanoma, J Clin Oncol, 2016;34(abstr):9541.

68. Gabrilovich DI, Ciernik IF, Carbone DP, Dendritic cells in antitumo immune responses. I. Defective antigen presentation in tumorbearing hosts, Cell Immunol, 1996:170:101-10.

69. Bol KF, Mensink HW, Aarntzen EH, et al., Long overall survival after dendritic cell vaccination in metastatic uveal melanoma patients, Am J Ophthalmol, 2014;158:939-47.

70. Middleton M, Steven NM, Evans TJ, et al., Safety, pharmacokinetics and efficacy of IMCgp100, a first-in-class soluble TCR-antiCD3 bispecific t cell redirector with solid tumour activity: Results from the FIH study in melanoma, $J$ Clin Oncol, 2016;34(abstr)3016.

71. Falchook GS, Lewis KD, Infante JR, et al., Activity of the oral MEK inhibitor trametinib in patients with advanced melanoma: a phase 1 dose-escalation trial, Lancet Oncol, 2012;13:782-9.

72. Carvajal RD, Sosman JA, Quevedo JF, et al., Effect of selumetinib vs chemotherapy on progression-free survival in uveal melanom a randomized clinical trial, JAMA, 2014;311:2397-405.

73. Carvajal RD, Schwartz GK, Mann H, et al., Study design and rationale for a randomised, placebo-controlled, double-blind study to assess the efficacy of selumetinib (AZD6244; ARRY-142886) in combination with dacarbazine in patients ARRY-142886) in combination with dacarbazine in patients
with metastatic uveal melanoma (SUMIT), BMC Cancer, 2015;15:467.

74. Adjei AA, LORusso P, Ribas A, et al., A phase I dose-escalation study of TAK-733, an investigational oral MEK inhibitor, in patients with advanced solid tumors, Invest New Drugs, 2017;35:47-58

75. Keating GM, Santoro A, Sorafenib: a review of its use in advanced hepatocellular carcinoma, Drugs, 2009;69:223-40.

76. Mouriaux F, Servois V, Parienti JJ, et al., Sorafenib in metastatic uveal melanoma: efficacy, toxicity and health-related quality of life in a multicentre phase II study, Br J Cancer, 2016;115:20-4 77. Daud A, Kluger HM, Edelman G, et al., Activity of cabozantinib in metastatic uveal melanoma: Updated results from a phase II randomized discontinuation trial (RDT), J Clin Oncol, 2013;31:(atstr)9094.

78. Ambrosini G, Musi E, Ho AL, et al., Inhibition of mutant GNAQ signaling in uveal melanoma induces AMPK-dependent autophagic cell death, Mol Cancer Ther, 2013;12:768-76.

79. Carita G, Frisch-Dit-Leitz E, Dahmani A, et al., Dual inhibition of protein kinase $\mathrm{C}$ and p53-MDM2 or PKC and MTORC1 are novel efficient therapeutic approaches for uveal melanoma, Oncotarget 2016;7:33542-56.

80. Khalili JS, Yu X Wang 」, et al., Combination small molecule MEK and PI3K inhibition enhances uveal melanoma cell death in a mu mutant GNAQ- and 2012;18:4345-55.

81. Shoushtari AN, Kudchadkar RR, Panageas K, et al., A randomized phase 2 study of trametinib with or without GSK2141795 in patients with advanced uveal melanoma, I Clin Oncol, 2016;34:(abstr)9511.

82. Rosenberg SA, Yang JC, Sherry RM, et al., Durable complete responses in heavily pretreated patients with metastatic melanoma using T-cell transfer immunotherapy, Clin Cancer Res, 2011:17:4550-7.

83. Ott PA, Pavlick AC, Johnson DB, et al., A phase II study of glembatumumab vedotin (GV), an antibody-drug conjugate (ADC) targeting gpNMB, in advanced melanoma, J Clin Oncol, 2017;35:(abstr) 109.

84. Williams MD, Esmaeli B, Soheili A, et al., GPNMB expression in uveal melanoma: a potential for targeted therapy, Melanoma Res, 2010:20:184-90.

85. Landreville S, Agapova OA, Matatall KA, et al., Histone deacetylase inhibitors induce growth arrest and differentiation in uveal melanoma, Clin Cancer Res, 2012:18:408-16. 